\title{
Abordagem sócio histórica da creche em Portugal. $O$ caso de Vila Nova de Gaia (1883-1971): entre o nacional e o local ${ }^{1}$
}

\author{
Historical and social approach to nurseries in Portugal. \\ The Vila Nova de Gaia case (1883-1971): between the nation and the region. \\ Enfoque socio histórico del parvulario en Portugal. \\ El caso de Vila Nova de Gaia (1883-1971): entre el nacional y el local
}

\author{
Eva Baptista \\ Universidade do Porto (Portugal) \\ https://orcid.org/0000-0001-6880-9656 \\ evacristinabaptisa@gmail.com
}

\section{RESUMO}

As creches, durante a primeira centúria da sua existência, acolhiam crianças desde os primeiros meses de vida até à idade da entrada na escola e não até aos 3 anos como hoje são concebidas, aliando nos seus propósitos higienistas e eugénicos, não só a procura da redução da mortalidade infantil mas, também, a educação da criança em idade pré-escolar extensível à mãe, à família, à comunidade e à nação. Foi nosso objetivo perceber o processo de implementação destes espaços de modernidade educativa em Vila Nova de Gaia até à década de setenta do século XX, um território com especificidades geográficas e sociodemográficas favorecedoras de um acompanhamento económico e cultural aparentemente recetivo à criação e sustentação de creches. Cruzando o percurso da implementação das creches em Portugal com o caso gaiense, rastreamos os impulsos das filosofias educativas e os obstáculos físicos e económicos que fizeram a sociedade portuguesa tardar em encarar a primeira infância como uma prioridade e a encarar a creche sem preconceitos.

Palavras chave: Creche; Vila Nova de Gaia; Portugal.

\footnotetext{
${ }^{1}$ Investigação inserida no Projeto: INOVAR - Roteiros da inovação pedagógica: Escolas e experiências dereferência em Portugal no século XX, PTDC/MHC-CED/0893/2014, financiado através de fundos nacionais da FCT/MCTES-PT. Teve a colaboração de Luís Alberto Alves e José António Afonso.
} 


\begin{abstract}
From their emergence and throughout the following one hundred years, nurseries took in and provided care to young children from their very first months of life till school age - unlike nowadays, with an age limit of 3 - allying thus sanitary and eugenic principles with the aim not only of reducing infant mortality rates, but also educating the child as well as mothers, family, community and nation. The present article aims a full comprehension of the implementation processes behind these innovating education institutions till the 70's of the $20^{\text {th }}$ century in Vila Nova de Gaia, a territory with geographic, social and demographic peculiarities which favoured the emergence and support of nurseries, both economically and culturally. Crossing the implementation processes of nurseries in Portugal with the regional situation of Vila Nova de Gaia, we track the impulses of educational philosophies and the obstacles - both physical and economic - which hindered the Portuguese society to take cognizance of the first childhood as a priority in itself and withdraw biases towards nurseries.
\end{abstract}

Key-words: Nursery; Vila Nova de Gaia; Portugal.

\title{
RESUMEN
}

Los parvularios, durante la primera centuria de su existência, acogían a niños desde los primeros meses de vida hasta la edad de la entrada en la escuela y no hasta los 3 años como hoy se concibe, aliando en sus propósitos higienistas y eugenésicos, no sólo la búsqueda de la reducción de la mortalidad infantil, sino también la educación del niño en edad preescolar extensible a la madre, a la familia, a la comunidad y a la nación. Fue nuestro objetivo percibir el proceso de implementación de estos espacios de modernidad educativa en Vila Nova de Gaia hasta la década de los setenta del siglo XX, un territorio con especificidades geográficas y sociodemográficas favorecedoras de un acompañamiento económico y cultural aparentemente receptivo a la creación y sostenimiento de los parvularios. Cruzando el camino de la implementación de los parvularios v en Portugal con el caso de Vila Nova de Gaia, hemos rastreado los impulsos de las filosofías educativas y los obstáculos físicos y económicos que han hecho la sociedad portuguesa retrasar a la primera infancia como una prioridad y a encarar el parvulario sin prejuicios.

Palabras clave: Parvulario; Vila Nova de Gaia; Portugal. 


\section{Contexto legislativo e sociocultural da criação de creches em Portugal $^{2}$}

As creches, por razões óbvias, surgem nos centros industriais e rurais e, por regra, recebem crianças desde os primeiros meses de vida, apenas durante o período diurno. Embora, excecionalmente, pudessem atender a situações de viuvez ou doença, não tinham por objetivo receber órfãos, nem expostos (crianças abandonadas). Foram criadas dentro do quadro legal constitucional do associativismo oitocentista, uma vez que para se oficializarem formalizavam-se em associações, regidas pelos preceitos estatutários inerentes ao tipo de associações vulgarizadas em finais do século. Nasceram e sobreviveram a expensas da filantropia até à consolidação da democracia na década de oitenta do século XX. O essencial para o custeamento das despesas de uma creche (capital, mobiliário, utensilagem, géneros alimentares, etc.) proveio, numa fase inicial, de atos de benemerência intermitentes na frequência e valor mas, nos quais a Maçonaria foi constante interveniente (cf. BAPTISTA, 2018).

Em Portugal, consideram-se como as primeiras instituições educativas concebidas especificamente para crianças, as "Casas de Asilo da Infância Desvalida" criadas em 1834 com o objetivo proteger, educar e instruir crianças pobres, desde que acabada a criação de leite até aos sete anos de idade, e meninas até aos nove, de forma a libertar os pais para o trabalho. A necessidade deste tipo de instituições explica a sua rápida difusão, ao ponto de no dealbar da República prestarem assistência a cerca de 1520 crianças ${ }^{3}$.

No último quartel do século XIX, ao tempo que se dava a difusão das casas de asilo e das creches ia-se estruturando, em particular em Lisboa e no Porto, um pensamento em torno da educação infantil assente nos modelos de Pestalozzi e Fröebel ${ }^{4}$, fruto do movimento gerado pela "Sociedade de Instrução do Porto". A Carta de Lei de 2 de maio de 1878 de António Rodrigues Sampaio e a Carta de Lei de 11 de junho de 1880 referendada por Luciano de Castro $^{5}$, demonstravam já interesses mais pedagógicos que sociais, invocando a necessidade de educar as crianças na idade anterior à da estipulada como obrigatória e apelando, por isso, à criação de asilos de educação e de escolas infantis e ao auxílio da iniciativa particular na criação deste tipo de estabelecimentos ${ }^{6}$. Não obstante, apenas o jardim de infância Fröebel, fundado em 1882, no jardim da Estrela em Lisboa - um edifício construído de raiz para aplicação das modernas pedagogias - assume caráter excecional neste panorama paradoxal entre pedagogia divulgada e legislação promulgada e a efetiva realidade socioeducativa.

De finais de oitocentos, assinala-se, ainda, por um lado, o projeto da escola infantil de José Augusto Coelho ${ }^{7}$ que se pretendia edificar no Porto $^{8}$ e, por outro, a produção de alguma

\footnotetext{
${ }^{2}$ Este ponto e o seguinte foram desenvolvidos na publicação Associação das Creches de Santa Marinha. Espaço de Modernidade Educativa. Vila Nova de Gaia: Associação das Creches de Santa Marinha/CITCEM, 2018, no âmbito do referido projeto INOVAR.

${ }^{3}$ Sobre o alargamento desta rede institucional vd. GOMES, 1977, p. 20-21.

${ }^{4}$ Em 1875, Ramalho Ortigão já fazia menções a Fröebel e, em 1879, Rodrigues de Freitas, num discurso sobre instrução na Câmara de Deputados, refere-se à pertinência da educação infantil e dos jardins infantis fröebelianos. cf. GOMES, 1977, p. 28-50.

${ }^{5}$ José Luciano de Castro (1834-1914). Nos anos de 1852 e 1853 terá integrado a Maçonaria, na Loja "Pátria da Caridade". Entre 1857 e 1858 exerceu o cargo de presidente da Câmara Municipal da sua cidade natal, Aveiro. Foi ainda deputado em 1861, eleito pelo Partido Regenerador em Vila Nova de Gaia. Em Maio de 1879, os Progressistas assumiram o poder, ficando Luciano de Castro com a pasta do Ministério do Reino. Durante este período apresentou várias reformas, entre as quais a da Instrução Pública.

${ }^{6}$ Da década de oitenta, assinala-se no Porto, a criação das Escolas Normais (1882) e o patrocínio de bolsas no estrangeiro (Suíça) para especialização na área da educação infantil, bolseiros estes que depois da proclamação da República formarão as jardineiras para os serviços de instrução da Câmara Municipal do Porto (GOMES, 1977, p. 48).

${ }^{7}$ Foi um dos primeiros pedagogos modernos, autor de uma extensa bibliografia sobre ensino e educação, precursor do curriculum para a escola infantil portuguesa. Cf. BAIRRÃO, 1997, p 8-9.

${ }^{8}$ Projeto publicado em GOMES, 1977, p. 48-19.
} 
legislação relevante, de que é exemplo o regulamento do Decreto de 22 de dezembro de 1894, aprovado em 18 de junho de 1896, que se refere aos objetivos da educação pré-escolar e à formação de educadores. Finalmente, em 1896, através do Diário do Governo n. ${ }^{\circ}$ 141, de 27 de junho, determinam-se objetivos, condições e normas de funcionamento das escolas infantis, reconhecendo-se a necessidade de formação dos docentes para estas instituições (MARTINS, 2006, p. 106).

Ainda antes da promulgação da primeira legislação sobre creches em Portugal (decreto de 14 de abril de 1891), nascem na área urbana do "Porto" a creche do Bom Pastor (1877), a Aula Infantil do Torne (1883) e a creches de Santa Marinha (1888), seguindo-se as creches de Cedofeita (1891) e a creche da Afurada (1893).

Em 1906, no Colégio da Boavista, criou-se um jardim infantil, dirigido por uma jardineira alemã, onde se aplicava o método de Fröebel ${ }^{9}$. Aliás, até aos inícios do século XX, as instituições fundadas com vista o ensino infantil constituem aplicações da pedagogia fröbeliana. A Lei n. ${ }^{\circ} 233$ de 7 de julho de 1914, vem criar as Escolas Normais de Lisboa, Porto e Coimbra que vieram a substituir as Escolas de Ensino Normal e as de Habilitação ao Magistério Primário. Determinou, ainda, que os alunos nos dois últimos anos praticassem os conhecimentos adquiridos, através do ensino primário ou infantil nas Escolas Anexas às Normais o que implicava, portanto, que em cada Escola Normal existisse uma instituição educativa para crianças entre os quatro e os oito anos onde, segundo FERREIRA; MOTA; VILHENA, seria praticado o modelo pedagógico de Fröebel (2019, p. 17).

Implantada a República, os novos dirigentes movem esforços no sentido da "republicanização" da sociedade e nesse projeto atribuem prioridade à educação e, dentro desta, também à educação infantil (ministrada a partir dos 4 anos). O Decreto do Ministério do Interior emanado da Direção Geral de Instrução Primária (29 de março de 1911) e o Decreto de 23 de agosto reformulam o ensino infantil (primário e normal) e aventam a transformação dos estabelecimentos do tipo asilares (em que se inscrevem as creches ${ }^{10}$ ) em jardins-de-infância, mas está por apurar que estabelecimentos procederam às alterações sugeridas e em que moldes é que esse processo decorreu.

Em 1911, inaugura-se, em Coimbra, o primeiro Jardim-Escola João de Deus, um projeto da "Associação das Escolas Móveis João de Deus", destinado a crianças dos três aos sete anos de idade, ao qual se seguiram a criação de outros, ainda, durante a Primeira República.

A reforma de 1919 retomando a legislação anterior, regulamenta o decreto de Leonardo Coimbra (Decreto-Lei n. ${ }^{\circ}$ 5787-A de 10 de maio de 1919) ${ }^{11}$, sugere a utilização do material Fröbeliano e do método Montessori e reitera a necessidade de se criarem escolas infantis em todas as capitais de distrito e sedes de concelho (Cf. GOMES, 1977, p 76).

Em finais da segunda década do século XX, o método de Montessori difundido por Luísa Sérgio e António Sérgio concorria com o de Fröebel, apresentando-se mais consentâneo com a psicologia moderna e a pedagogia científica e mais atrativo para o movimento da Escola Nova (FERREIRA; MOTA; VILHENA, 2019, p. 18).

Em 1923, João Camoesas apresenta uma Proposta de Lei (22 de julho) relativo à reorganização da Educação Nacional, reforçando vários aspetos relativo à educação de infância e propondo a formação das "jardineiras infantis" em Faculdades de Ciências da Educação, o que só veio a acontecer mais de 60 anos depois.

\footnotetext{
${ }^{9}$ Em 1913 já não existia. Cf. GOMES, 1977, p. 50, 67.

10 «As creches, asilos, ou casas de educação onde se ministre o ensino a crianças de menos de 7 anos de idade, pertencentes ao Estado ou aos municípios, deverão sempre que possível, ser transformadas em escolas infantis». Decreto do Ministério do Interior de 29 de março de 1911, art. $^{\circ} 8$.

${ }^{11}$ Este decreto, entre outras considerações divide o ensino infantil em três secções (4-5 anos, 5-6 anos, 6-7 anos) e apela para que a preparação dos professores infantis seja feita a par dos professores do ensino primário, mas completada com visitas de estudo a creches, lactários, entre outras instituições de assistência social. Patenteia uma visão holística de ensino infantil e toma a chamada educação pré-escolar como continuidade e não como "inicio".
} 
No início da Ditadura Militar, face à «relutância que oferecem a indústria, as famílias e os próprios menores e mulheres e a dificuldade em regular e executar as medidas de proteção indispensáveis» (Diário do Governo n. ${ }^{\circ}$ 240/1927), os decretos n. ${ }^{\circ}$ s 14.498 e 14.535 de 29 e 31de outubro de 1927, respetivamente, vêm procurar "ressuscitar" o decreto de 1891, obrigando a que toda a indústria com mais de 50 mulheres devesse dispor de um local onde permanecessem as crianças até à idade de 1 ano e locais de amamentação nas restantes.

De um modo geral, o os primeiros anos que se seguiram ao golpe militar de 28 de maio, não vieram produzir ruturas em relação ao problema da educação infantil: «reconhecimento das suas vantagens, uma certa inflação legislativa e muito poucas realizações concretas» (GOMES, 1977, p. 90). Deste período, salienta-se o papel de Irene Lisboa $^{12}$ e de Ilda Moreira ${ }^{13}$ na criação das secções de educação infantil nas Escolas da Tapada da Ajuda, em Lisboa. Irene chegou a propor um programa de educação infantil vanguardista fortemente influenciado pelo movimento da Escola Nova (BAIRRÃO; VASCONCELOS, 1997: 10; FERREIRA; MOTA; VILHENA, 2019, p.21).

Sob o lema "Façamos felizes as nossas crianças", o médico e professor Bissaya Barreto levou a cabo um plano iniciado em 1936 com o objetivo de oferecer às grávidas, às mães e às crianças de fracos recursos, melhores condições de vida, apoiou uma vasta obra assistencial e educativa infantil no centro do país.

A entrada para o Governo de Carneiro Pacheco (1936) vai fazer entregar a superintendência da educação infantil à "Obra das Mães para a Educação Nacional”, à qual competia promover e assegurar em todo o país a educação infantil pré-escolar em complemento da ação da família e, através do Decreto-Lei n. ${ }^{\circ}$ 28.081, de 9 de outubro de 1937, o ensino infantil é extinto. O argumento invocado para aquela medida - falta de recursos para expansão da rede e a igualdade de tratamento dos cidadãos - era claramente falacioso. O Estado Novo defendia que a educação era uma função das famílias e não do Estado, era contra a coeducação das crianças e, em certo momento, as instituições educativas para crianças em idade pré-escolar chegaram as ser vistas como um fator de desagregação da família. Se aliarmos a isto, o facto de alguns pensadores e pedagogos terem sido acusados de dissolução de costumes, percebe-se que combater o ensino infantil foi um terreno fértil para articular o discurso autoritário sobre as camadas populares e canalizá-lo também para a campanha anticomunista apoiada por alguma intelectualidade que exaltava as virtudes do pouco instruído povo português (FELGUEIRAS, 2012: 36-7).

O Estado Novo vai desresponsabilizar-se da educação infantil, entregá-la às famílias e relegá-las ao lar, o local por excelência do desenvolvimento do «sentimento e do caráter» arreigado a uma formação para a vida centrada na educação para o trabalho, na transmissão dos usos e costumes. Face a estes objetivos, a escola era «como a caserna, despersonalizante. As condições da família são muito superiores às da escola para educar até aos sete anos. Mas estarão as famílias à altura da sua função educativa?» Era aqui que surgia o papel do Estado: educar as famílias e melhorar e educação do povo ${ }^{14}$. Não bastava construir creches, lactários, jardins-de-infância «era preciso ir atrás, à família» ${ }^{15}$. Impunha-se reduzir ao

\footnotetext{
${ }^{12}$ Irene do Céu Vieira Lisboa (1892-1958) foi escritora e professora do ensino primário, do ensino infantil e da Escola Normal de Lisboa. É uma referência no campo da educação portuguesa no século XX, estando ligada ao desenvolvimento da educação de infância e à difusão das ideias pedagógicas da Escola Nova. Na década de trinta, durante o desinvestimento da educação pré-escolar, é afastada das funções de inspetora-orientadora até que, em 1937, com a extinção das classes infantis vê-se compelida a abandonar a docência e a optar pela reforma, passando a dedicar-se à divulgação do seu pensamento pedagógico e à escrita (LEANDRO, 2003: 773-784).

13 Ilda da Ascensão Moreira (1894-1980), professora do ensino primário e infantil. Destacou-se pela valorização do ensino infantil assente na renovação dos métodos pedagógicos, através da prática (na escola da Tapada da Ajuda com Irene Lisboa) e dos seus escritos na Imprensa (NÓVOA (dir.), 2003: 942-943).

${ }^{14}$ Discurso de Pacheco Amorim (AR-DP - Diário [...], n. ${ }^{\circ} 181,1938: 623$ ).

${ }^{15}$ Afirmação de Maria Luiza Van Zeller (AR-DP - Diário [...], n. ${ }^{\circ}$ 63,1944: 257).
} 
mínimo a intervenção das escolas infantis e o trabalho feminino fora do lar: «A melhor maneira de defender as crianças é proteger a família, é fazer com que a mãe viva no lar, isto é que não seja desviada para trabalhar fora dele» ${ }^{16}$.

Assim, se em finais do século XIX e primeiras duas décadas do século XX se chegou a advogar a universalização da educação da infância independentemente da sua classe social, assente num nova conceção de infância que considerava necessária uma certa "profissionalização da maternidade" e a instrução feminina para uma educação científica das crianças (FERREIRA; MOTA; VILHENA, 2019, p. 9-11), a partir do Estado Novo ao mesmo tempo que se concebe uma maternidade doméstica, não planeada, «observou-se um grande retrocesso na história da educação de infância, voltando esta a ser considerada como tendo uma missão essencialmente assistencial, sendo depreciada a sua função educativa» (CARDONA, 1997, p. 50). Paulatinamente, durante o Estado Novo, a educação infantil ficou confinada a instituições particulares sem objetivos educacionais definidos e sem qualificações específicas requeridas.

Fig. 1 - Capa da Mocidade Portuguesa Feminina: Boletim Mensal, com a seguinte legenda: «Ninho já habitado: berço oferecido pela M.P.F. a uma mãe de onze filhos».

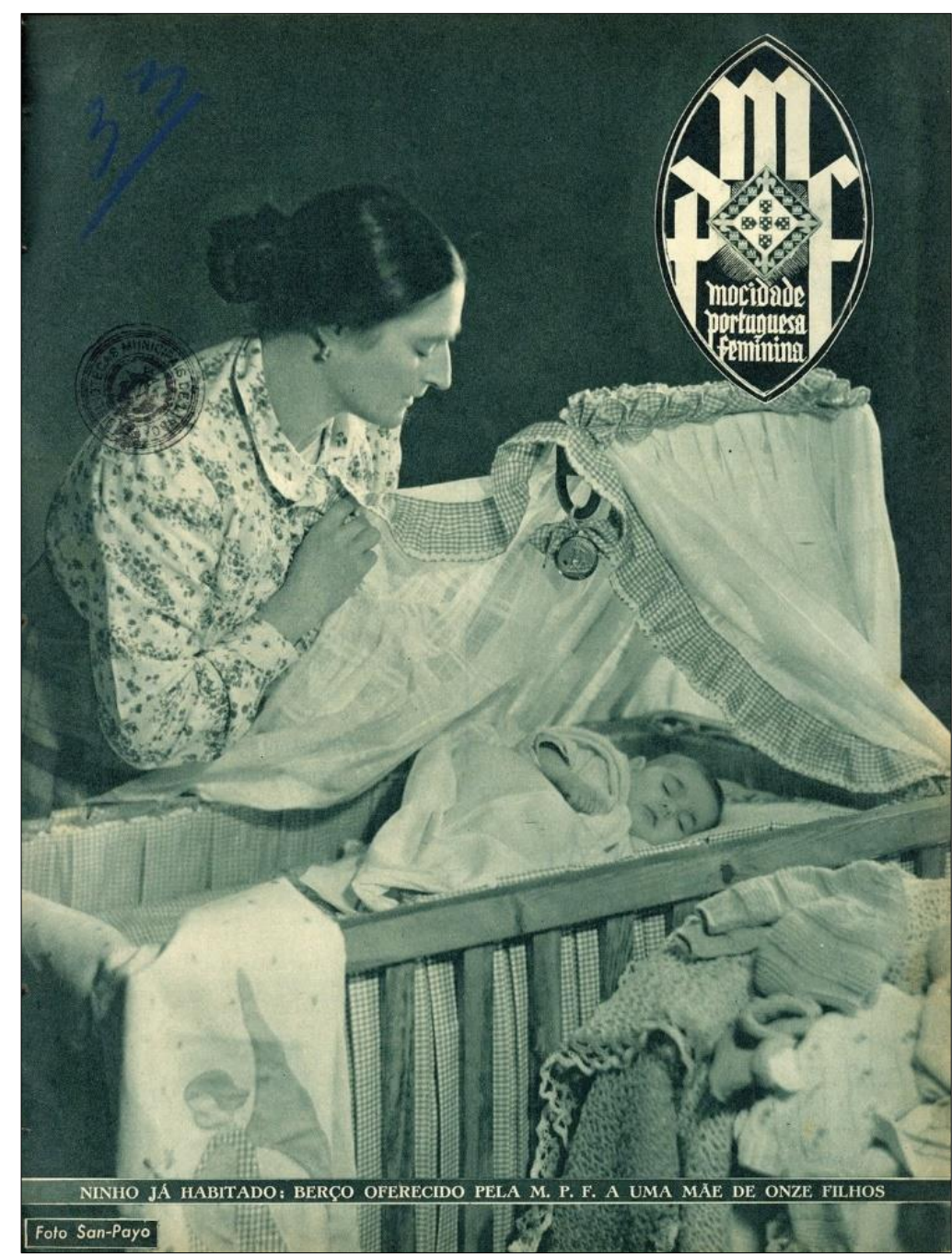

Fonte: Mocidade Portuguesa Feminina: Boletim Mensal, 1942, n.33:1.

\footnotetext{
${ }^{16}$ Discurso de Pacheco Amorim (AR-DP - Diário [...], n. ${ }^{\circ}$ 181, 1938: 623).
} 
O Fundo de Socorro Social, criado através do Decreto n. 35.427 de 5 de abril de 1945, vem "resolver" o problema ao estado e às indústrias criado pelas mães operárias: as empresas passam a estar desobrigadas de criar creches mediante o pagamento de $6 \$ /$ mês por cada mulher ao serviço. Em consequência, a título de exemplo dos concelhos de forte industrialização, registamos que, em Vila Nova de Gaia, no ano de 1969, somente 385 crianças usufruíam de «proteção e formação em creches e infantários ${ }^{17}$ entre 25974 crianças até aos seis anos filhas de beneficiários da Previdência, e que em Guimarães no ano de 1971, não havia uma única creche em funcionamento junto das empresas fabris (AR-DP - Diário [...], n. $\left.{ }^{\circ} 98,1971\right)$.

A adesão ao "Projeto Regional do Mediterrâneo" significou o início de uma viragem que teve o seu auge, no governo de Marcelo Caetano, com a Reforma de Veiga Simão (Lei $5 / 73$, de 14 de julho) mas que, de resto, apresenta como objetivos para o ensino pré-escolar os mesmos propostos pela legislação republicana.

Gradualmente, a entrada das mulheres no mundo de trabalho generaliza-se a todas as classes sociais. Em simultâneo, nos anos 60, verifica-se o início de um grande processo de migração para as cidades e um aumento da longevidade o que fez com que o número de crianças passasse a ser cada vez menos numeroso em relação à globalidade da população e, por conseguinte, a sua sobrevivência e educação suscitam outra atenção, sendo que a educação das crianças mais pequenas passa a ser mais valorizada devido, também, ao desenvolvimento da psicologia e da sociologia. Por outro lado, com a melhoria generalizada das condições de vida, crescem as expetativas em relação ao futuro das crianças, ganhando a escola maior relevância como meio de ascensão social. Por outro lado, ainda, as taxas de insucesso escolar vieram contribuir para a valorização do papel da educação de infância na preparação precoce das crianças (CARDONA, 1997, p. 58). Apesar do grande atraso em relação aos outros países da Europa, as mutações sociais derivadas da crescente industrialização também se fizeram sentir em Portugal: a migração das famílias das aldeias para as grandes cidades fez-se sentir na viragem para a década de 60; o número de crianças inscritas no ensino primário aumentou; aumentando também o número de trabalhadoras assalariadas, exponenciado pela necessidade da entrada de mulheres no mundo de trabalho, devido ao início da Guerra Colonial (CARDONA, 1997, p. 59).

Em 1974, em conformidade com o IV Plano de Fomento, previa-se a remodelação de mais de meia centena de creches (infantários) e a criação de mais 25 (AR-DP - Diário [...], n. ${ }^{\circ} 34,1974$ ), mas é o pós-25 de abril, em frenesim pela Democracia, que vai gerar um vasto conjunto de iniciativas apoiadas pelos Municípios e pelo Estado, produzindo-se, também, uma vasta documentação jurídico-legal relativa ao setor pré-escolar, objetivando a sua integração no sistema oficial e, ao mesmo tempo, configurando-se as linhas gerais de um plano de desenvolvimento da rede institucional pública (MARTINS, 2006: 103).

A educação de infância surge como um serviço público pela Lei n. $^{\circ} 5 / 77$ cingindo a educação pré-escolar àquela que se destina às crianças dos três aos cinco anos de idade, ficando as creches sob a tutela do hoje denominado Ministério da Solidariedade e Segurança Social (IPSS).

É a Lei de Bases do Sistema Educativo, Lei n. ${ }^{\circ}$ 46/86 de 14 de outubro, que pela primeira vez inclui a educação das crianças dos três aos seis anos de idade na definição de Educação Básica. Porém, não obstante a abordagem ecológica de todo o processo educativo ${ }^{18}$, a "creche" (educação até aos três anos de idade) ficou de fora do sistema educativo nacional, exclusão reiterada na revisão de 1998 não se reconhecendo que a educação tem início aos zero anos (apud CARVALHO, 2014, p. 20). O relatório do estudo temático "Educação e Cuidados

\footnotetext{
${ }^{17}$ Intervenção de Leonardo Coimbra, filho (AR-DP - Diário [...], n. ${ }^{\circ} 81,1969$ ).

18 Sendo consideradas todas as influências do meio, as quais intervém de forma direta ou indireta no desenvolvimento da criança. Cf. CARDONA, 1997, p. 22-23.
} 
para a Infância em Portugal" da OCDE (2000) atribuiu essa decisão a razões financeiras e «a uma apreensão com a passagem de um sector tão dispendioso para a tutela do Ministério da Educação» (apud TADEU, 2014, p. 167).

As instituições de educação pré-escolar permaneceram assim com dupla tutela: os jardins- de-infância públicos estão sob a alçada do Ministério da Educação e as IPSS, onde se incluem as creches, sob a tutela do Ministério da Solidariedade e Segurança Social. «Esta dupla dependência pedagógica e administrativa expressa a indefinição quanto aos objetivos e funções da educação de infância» (DIAS; CORREIA; PEREIRA, 2013, p. 667).

Todavia, apesar de a legislação incluir apenas a educação pré-escolar a partir dos 3 anos, não abrangendo a educação em creche considera-se, de acordo com a Recomendação do Conselho Nacional de Educação, que esta é um direito da criança e por conseguinte, importa que haja uma unidade em toda a pedagogia para a infância e que o trabalho profissional com crianças antes da entrada na escolaridade obrigatória emane de fundamentos comuns. As atuais Orientações Curriculares para a Educação Pré-Escolar (2016) vêm reiterar esta indefinição em torno da creche patente na ambiguidade entre legislação/ prática pedagógica e exigência habilitacional/ desvalorização profissional cujo esclarecimento se tem vindo a adiar.

\section{A paisagem urbana gaiense na viragem para o século $\mathrm{XX}$}

Vila Nova de Gaia é um território extenso e contrastante em termos paisagísticos e socioecónomicos, sendo que na viragem para o século XIX, a azáfama comercial e industrial nas proximidades da foz do Douro e do caminho-de-ferro divergiam com a ruralidade e o conservadorismo da maior parte do território. As freguesias de Santa Marinha e de Mafamude ${ }^{19}$ constituíam um território em processo de transição de uma sociedade camponesa para uma sociedade em vias de industrialização e urbanização, vivendo um período de reorganização social. $\mathrm{O}$ ambiente de desenvolvimento aqui verificado funcionou como fator de atração para investidores nacionais e internacionais e para membros de famílias rurais numerosas das envolvências e do interior do país.

O proletariado deslocado habitava as designadas "casas de malta"20, uma espécie de camaratas ou dormitórios a preço acessível que alojavam trabalhadores na cidade durante a semana. As condições de insalubridade, aliada à concentração populacional facilitavam o contágio da tuberculose, da varíola, do sarampo e o aparecimento de várias outras doenças. As modernas pontes férreas (D. Maria Pia e D. Luís) tinham-se tornado o local dileto para os desafortunados exporem a sua miséria e as suas doenças (AR-DP - Diário [.... ], n. ${ }^{\circ}$ 120, 1914 : 30). Este estado de insalubridade, pauperismo e de degradação social também eram denunciados na imprensa local ${ }^{21}$, chegando um jornal, em 1897, a lançar um plebiscito aos intelectuais e capitalistas da região sobre a possibilidade da anexação de Gaia ao Porto face aos vários problemas ${ }^{22}$ com que se debatia este jovem concelho.

\footnotetext{
${ }^{19}$ Sobre o processo de urbanização e industrialização de Mafamude vd. GUIMARÃES, 2014: 5-24.

${ }^{20}$ A propósito da história da fundação de uma Tuna centenária de Vila Nova de Gaia descreve-se a vivência de alguns membros da agremiação que trabalhavam durante a semana no Porto: «O artífice saía pela noite velha de domingo, sacola ao ombro com a saborosa boroa para toda a semana, e algo mais que lhe permitisse cozinhar nos minguados quartos alugados, junto ao rio. Calcorreava os quinze quilómetros de distância de maus caminhos, sob chuva ou frio, em magotes, dado que os sítios eram ermos e a gatunagem abundava» (PEDROSA, 1984, p. 47).

${ }^{21}$ Por exemplo, na Luz do Operário em 1895, na altura em que um surto de varíola fazia aumentar a mortalidade. Durante o período em estudo, a varíola foi uma das doenças mais devastadoras, assim como a tuberculose, também conhecida por "peste branca". Vila Nova de Gaia escapou ao surto de peste bubónica que ocorreu no Porto, em 1899, sendo que os efeitos que se sentiram foram, sobretudo, de ordem económica devido ao abrandamento do fluxo comercial originado pelo entrincheiramento da cidade no cordão sanitário. Sobre o assunto vd. COSTA, 2005, p. 45-58.

${ }^{22}$ Como por exemplo, falta de meios de condução rápida e cómoda, falta de tribunal, prisões vexatórias, inexistência de conservatória, aumento da contribuição predial e más condições de salubridade.
} 
Vila Nova de Gaia era um dos concelhos mais populosos do país. Todavia, a subida da taxa de mortalidade infantil nos primeiros anos do século XX (1906) lançou a suspeita de ação criminosa e motivou o subdelegado de Saúde deste município a convocar todos os médicos do concelho a fim de se apurarem causas e diligenciarem soluções de combate ao flagelo. $\mathrm{Na}$ referida reunião, a intervenção criminosa como fator do acréscimo da letalidade infantil não teve acolhimento, apontando-se antes como grandes causas a incúria, a ignorância e a miséria das mães. Urgia, portanto, educar as mães sobre a alimentação da primeira infância e, como estas eram analfabetas, as instruções necessárias seriam veiculadas pelos párocos $(O$ Portucalense, 1906).

A explicação para o elevado número de mortes na primeira infância, era atribuída à "indústria" das criadeiras que vinha a desenvolver-se sem fiscalização. Com efeito, muitas centenas de trabalhadoras assalariadas gaienses (manipuladoras de tabaco, vendedeiras de leite, frutas, pão, peixe, etc.) acorriam diariamente ao Porto e outras, sem saírem do concelho, trabalhavam como engarrafadeiras, rolheiras, fiandeiras, oleiras, etc., gerando-se a necessidade de recorrer a criadeiras, ou seja, mulheres que cuidavam dos filhos das operárias até ao seu regresso da fábrica para o lar. Conclui-se que não obstante a existência de boas criadeiras, certo era que o desenvolvimento do mister e a sua sucessão tinha-o transformado numa verdadeira indústria, em que a saúde da criança era sacrificada à ganância. Sobre esta profissão, recaíam fortes suspeitas da morte de muitas crianças, vitimadas por alimentação imprópria, ministrada por ignorância ou mesmo por intenção criminosa. Apelava-se por isso à fiscalização da atividade, a exames cadavéricos, à inspeção do leite e ao incentivo de boas práticas através da instituição de prémios atribuídos a criadeiras cumpridoras. Apelava-se, também, a um quadro de proteção das mulheres grávidas com base naquilo que já se vinha a fazer no Porto, ou seja, através da filantropia patronal e do mutualismo operário, elencandose, inclusivamente, alguns exemplos com o intuito de cativar os industriais de Gaia para este tipo de benemerência, nomeadamente a Fábrica José Mariani e a Fábrica de Moagem de J. Andressen (O Portucalense, 1906, n. ${ }^{\circ} 33$, p. 1).

Nos ambientes político-sociais ${ }^{23}$ e académicos, fervilhavam discursos, conferências e publicam-se teses com vista à minimização dos problemas despontados pelo processo de industrialização. De acordo com a opinião sentida entre as ciências médicas, Ferreira de Castro, afirma ser preciso ir muito mais além do que a campanha informativa por intermédio dos párocos. Para combater a mortalidade infantil, era necessário tornar efetiva a proteção das operárias grávidas através de socorro pecuniário e licença durante o último mês de gravidez e as quatro primeiras semanas depois do parto e, ainda, da garantia da continuidade do posto de trabalho. Era também necessário tornar efetiva a salvaguarda das crianças com recurso à criação de comissões de proteção da primeira infância (uma em cada freguesia) destinadas a instruir as mães, as amas e as criadeiras encarregues da vigilância das crianças e da fiscalização do leite no concelho. Defendia, ainda, a necessidade da criação de instituições de apoio ao proletariado nomeadamente, lactários, dispensários e creches. No entanto, apenas dois «estabelecimentos regularmente montados existem em todo o concelho para uma população de perto de 3000 crianças de menos de 1 ano» (O Portucalense, 1906, n. ${ }^{\circ} 33$, p. 1).

Com efeito, estas questões relacionadas com a especificidade da criança e da sua proteção estavam também latentes nos ambientes socioprofissionais e políticos de Vila Nova de Gaia. Na viragem para o século XX, destacamos Ângelo Vaz, genro de Bernardino Machado que veio a ser por duas vezes presidente da República Portuguesa, ambos maçons. Natural de Lisboa, frequentou a escola Fröebel no jardim da Estrela, iniciando o ensino primário na Escola Municipal n. ${ }^{\circ} 11$ de Lisboa, formou-se em medicina, especializando-se em pediatria (ABREU, 2013, p. 1418-9). Com consultório no Porto, tratava de crianças e instruía

\footnotetext{
${ }^{23}$ Sobre a Infância como questão supranacional vd. TOMÉ, 2010, p. 482-4.
} 
as mães relativamente a práticas higiénicas e alimentação. Uma notícia da época dá conta, inclusivamente, da sua intenção, entre outras, em criar uma "Escola de Mães", além da organização de colónias infantis (A Defesa, 1906, n. ${ }^{\circ}$ 51, p. 3). Na sua tese inaugural, apresentada à Escola Médico-cirúrgica do Porto, intitulada Neo-Malthusianismo, disserta sobre controversos assuntos relacionados com o «amor livre» e a maternidade planeada, convicto de que «um bom nascimento, uma boa educação e uma boa organização social preparará o advento de uma nova era de felicidade» e de que a fecundação humana constituía uma responsabilidade moral e social (VAZ, 1902, p. 112, 115).

O sonho e a aspiração dos neo-malthusianos é a formação duma humanidade nova, vigorosa e pujante na sua vida física e mental, graças a uma seleção conscientemente querida e livremente aceite (VAZ, 1902, p. 107). [...]

Converta-se numa realidade bem manifesta a plena expansão do desejo sexual, a livre união dos sexos, sem as peias que na sociedade contemporânea tanto a reprimem e pervertem. Depois, quando a mulher, emancipada para sempre da opressão e do jugo do homem, puder, consciente e livre, escolher o companheiro preferido para uma existência em comum, a livre maternidade será a consequência lógica do amor livre. A mulher terá o legítimo direito e a liberdade de escolher a época em que deseja ser mãe.

O amor livre e a livre maternidade são os termos indissociáveis duma conceção bem mais larga da família. Uma vez efetuada uma união sexual, perfeitamente liberta de todos os convencionalismos que dominam e escravizam a atual instituição da família, o homem e a mulher cooperarão, de comum acordo, na génese de uma descendência mais forte e mais perfeita (VAZ, 1902, p. 111).

Ângelo Vaz colaborou em vários jornais e, entre outros estudos, publicou As mães. Conselhos para uma boa higiene e alimentação das crianças. Tinha também relações profissionais e políticas com personalidades de Gaia, tendo sido médico efetivo d' «A Infantil. Associação de Proteção às Crianças (Socorro Mútuo)» (A Defesa, 1906, n. ${ }^{\circ}$ 51, p. 3) e, mais tarde, professor e médico escolar na Escola Superior de Gaia. A mencionada associação foi criada em 1905, com vista a atuar numa área alargada que incluía os dois bairros do Porto e as freguesias de Santa Marinha, Mafamude e Oliveira do Douro. Tinha por principais finalidades socorrer os filhos dos associados até à idade de catorze anos, através de serviços médicos, medicamentos e banhos de mar e socorrer os sócios impossibilitados de trabalhar e fazer o funeral do sócio e respetivo agregado(ADP, Estatutos de A Infantil. Associação de Socorros Mútuos, 1909).

António de Almeida Garret, além de político e professor, foi também figura influente na área do higienismo e da pediatria. Enquanto presidente da Junta Geral do Distrito do Porto, proferiu uma conferência pública no edifício-sede da Associação de Creches de Santa Marinha, enaltecendo este tipo de instituições na sua função profilática e educadora da população pobre (ADCSM - Livro de Actas [...] [1929-1936]: 70v). 
Já durante o Estado Novo, destaca-se a ação do médico Leonardo Coimbra ${ }^{24}$, residente em Vila Nova de Gaia onde foi diretor do Sanatório de D. Manuel II (1950-1955) e onde fundou a «Associação Protetora da Criança contra a Crueldade e o Abandono», em 1953, obra completada em 1960, com a abertura de um Centro de Recuperação de Crianças. Esta instituição visava criar condições médico-sociais e psicopedagógicas para crianças socialmente excluídas por manifestarem desvios comportamentais, suscetíveis de reeducação ou défices intelectuais. É, hoje, uma IPSS, presidida por um dos filhos do fundador. Fundou, ainda a revista $A$ criança (1954-5) com sede neste concelho e que tinha, entre outros objetivos, a defesa dos interesses das crianças.

\section{As creches em Vila Nova de Gaia}

Vila Nova de Gaia, a par do Porto, Lisboa e Coimbra viram nascer as primeiras creches em Portugal. Este pioneirismo justifica-se, por um lado, pelo crescimento comercial e industrial, acompanhado de crescente densidade populacional e, por outro, pela presença de um ambiente político-social e académico, divulgador e defensor de instituições de proteção/educação popular de que as creches são exemplo.

Mapa I - Creches em Portugal Continental entre 1852 e 1972 por municípios.

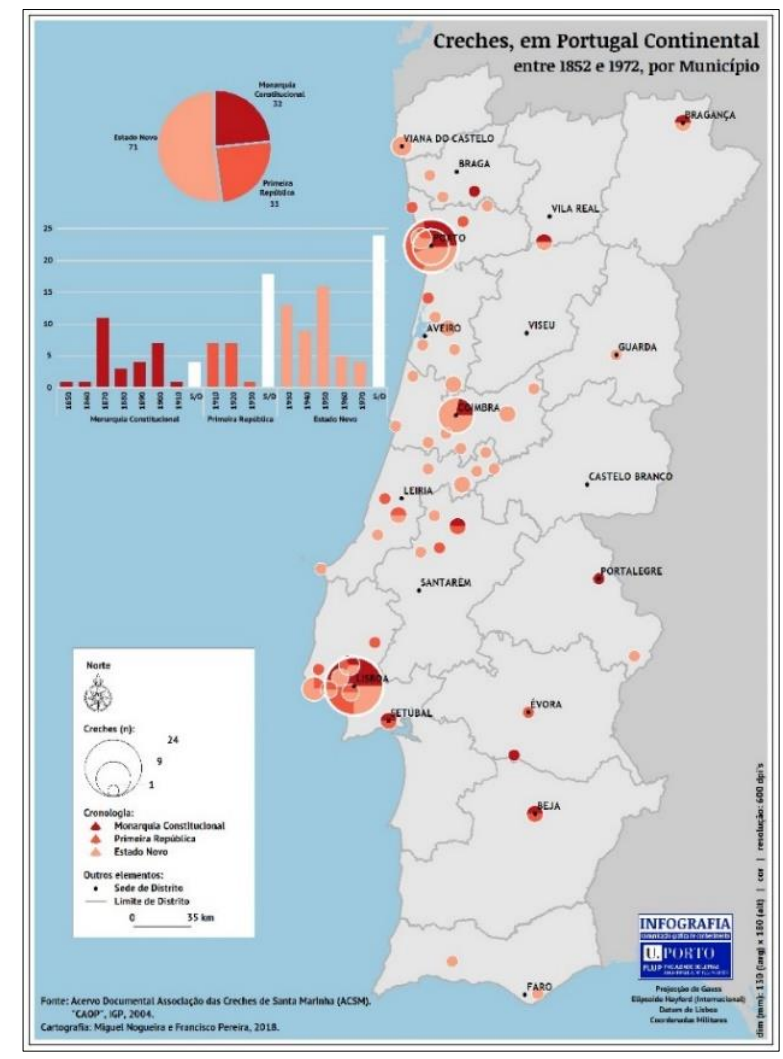

Fonte: Arquivo Documental da Associação das Creches de Santa Marinha; Cartografia de Miguel Nogueira e Francisco Pereira, 2018.

24 Leonardo Augusto Coimbra (1914-1970), filho do professor Leonardo José Coimbra, além do elencado exerceu, entre outros cargos, o de Médico-chefe de um posto da Caixa de Previdência e Abono de Família do Distrito do Porto (1965) e o de diretor clínico do Sanatório de Louredo da Serra e da Siderurgia do Marão. Fundou também instituições para recuperação de crianças portadoras de deficiência, na Senhora da Hora, em Matosinhos e em Gemunde-Famalicão. Cf. Universidade do Porto, Antigos Estudantes Ilustres: https://sigarra.up.pt/up/pt/web_base.gera_pagina?p_pagina=antigos\%20estudantes\%20ilustres $\% 20$ - \%20leonardo\%20augusto\%20coimbra 
Quadro I - As Creches em Vila Nova de Gaia (1883-1972)

\begin{tabular}{|c|c|}
\hline \multicolumn{2}{|c|}{ QUADRO 1 - AS CRECHES EM VILA NOVA DE GAIA (1883-1972) } \\
\hline Data de criação & Designação \\
\hline 1883 & Aula Infantil do Torne \\
\hline 1888 & Creche de Santa Marinha \\
\hline 1893 & $\begin{array}{l}\text { Creche do Colégio Nossa Senhora do Rosário (Convento Corpus } \\
\text { Christi) / Colégio-Creche Nossa Senhora do Bonança }\end{array}$ \\
\hline 1893 & Creche da Afurada - filial da Creche de Santa Marinha \\
\hline $1894 / 1915$ & Creche da Fábrica Cerâmica das Devesas \\
\hline 1942 & Creche da Coats \& Clark \\
\hline $1944-1950$ & Creche de Arcozelo \\
\hline 1949 & Creche da Real Vinícola \\
\hline 1956 & Creche da Sociedade dos Vinhos do Porto Constantino, Lda \\
\hline 1971 & Creche da COTESI - C. a de Têxteis Sintéticos SARL, Grijó \\
\hline
\end{tabular}

Fonte: Baptista, 2018

No território em estudo, foi o assistencialismo protestante que levou a cabo a primeira experiência ao nível do pré-escolar. Já em 1883, Diogo Cassels incluiu na sua oferta educativa uma "Aula infantil" que, a partir de 1894, passa a funcionar sistematicamente. Destinava-se a crianças com idade inferior a sete anos, na qual se ensinavam rudimentos de leitura e que tinha por objetivo «entreter as crianças e tirá-las da rua» ${ }^{25}$.

A criação da Creche de Santa Marinha, em 1888, uniu personalidades de ideologias e credos diversos. Além de burgueses e republicanos, entre os seus fundadores estavam membros da conservadora aristocracia, como o conde de Campo Belo, tendo este último, inclusivamente, protegido uma creche que existiu no convento Corpus Christi na década de noventa de oitocentos, a cargo da Irmandade de Nossa Senhora do Rosário e S. Domingos de Gusmão $^{26}$, integrada no designado Colégio Nossa Senhora do Rosário, sob a ação educativa das Irmãs Hospitaleiras dos Pobres pelo Amor de Deus. Dificuldades várias, potencializadas pelo anticlericalismo exacerbado da República, vieram a obrigar a transferência desta instituição para a rua do Castelo, onde tomou a designação de Colégio-creche Nossa Senhora do Bonança pela proximidade de uma capela com esta invocação ${ }^{27}$. A creche de Santa Marinha teve o seu início na rua das Costeiras (atual rua Dr. António Granjo), n. ${ }^{\circ}$ 22, 2. ${ }^{\circ}$, propriedade de um dos fundadores, acérrimo republicano e maçom, João Rodrigues Valente Perfeito. Depois, foi transferida para uma creche para uma parte do prédio onde estava

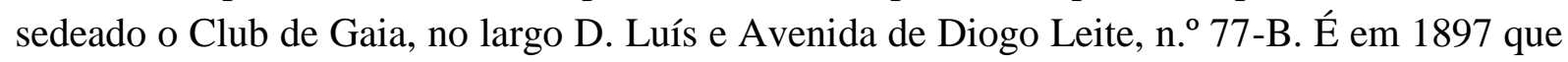

\footnotetext{
${ }^{25}$ Relato de Diogo Cassels em A Mocidade, 1898, n. ${ }^{\circ}$ 11: 2-3. Sobre a ação de Diogo Cassels vd. SILVA, 2018.

${ }^{26}$ Em 1893 já existia, mas em 1905, segundo relato do diretor de obras públicas do Porto, não havia dela vestígios, cf. Crónica do Centenário [...]: 996, 999.

27 Em 1927, dá-se a deslocação definitiva do Colégio Nossa Senhora da Bonança para o palacete da Bandeira, por interferência de Manuel Moreira Barros, sob a proteção das Irmãs, agora designadas Franciscanas Hospitaleiras Portuguesas.
} 
a sede da instituição se instala, definitivamente, num palacete, virado para o rio Douro, até aos dias de hoje.

Fig. 2 - Aspeto de sala da Creche de Santa Marinha, década de oitenta, século XX.

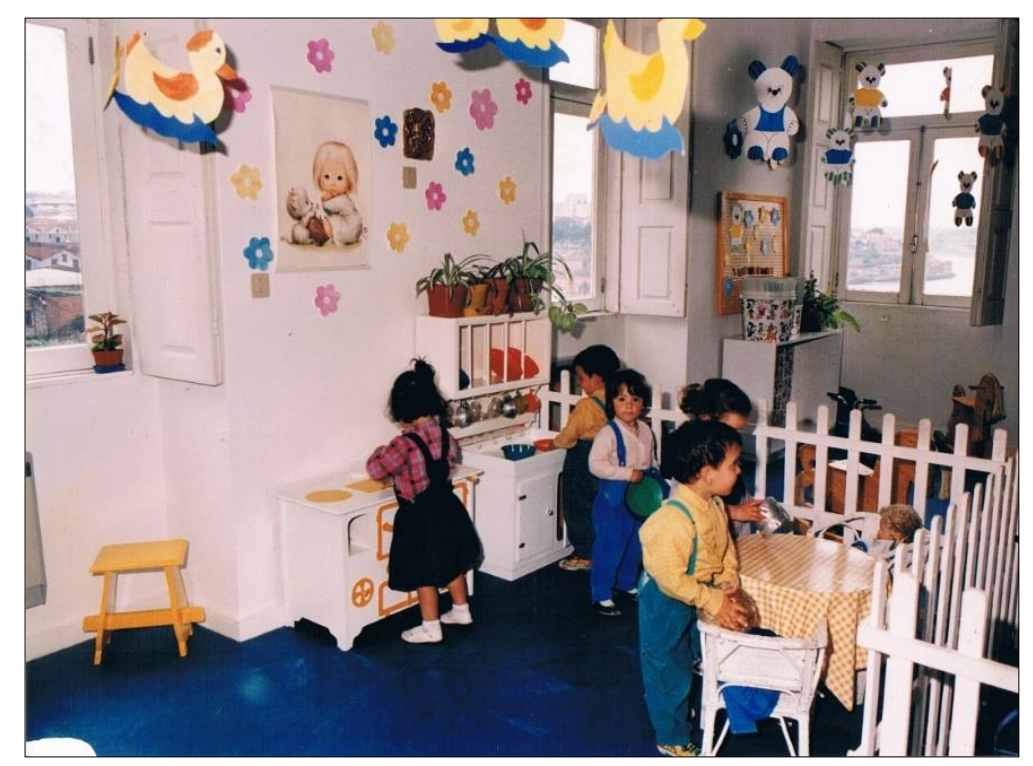

Fonte: Arquivo Documental da Associação das Creches de Santa Marinha.

A Associação de Creches de Santa Marinha constitui-se em 1893 com a anexação da creche da Afurada, erguida no monte do Cavaco. A origem desta creche está relacionada com trágico naufrágio em que perecerem mais de cem pescadores, trinta e cinco dos quais do lugar da Afurada. A iniciativa foi do jornal O Comércio do Porto que conjuntamente com o diretor da creche de Santa Marinha, o maçom, Artur Ferreira de Macedo, se reúnem esforços para a construção de um edifício de raiz junto desta comunidade piscatória gaiense. Vicissitudes diversas levaram a que deixasse de exercer funções educativas na década de cinquenta (vd. BAPTISTA, 2018, p.30).

Fig. 3 - Creche da Afurada (filial da Associação de Creches de Santa Marinha), década de trinta.

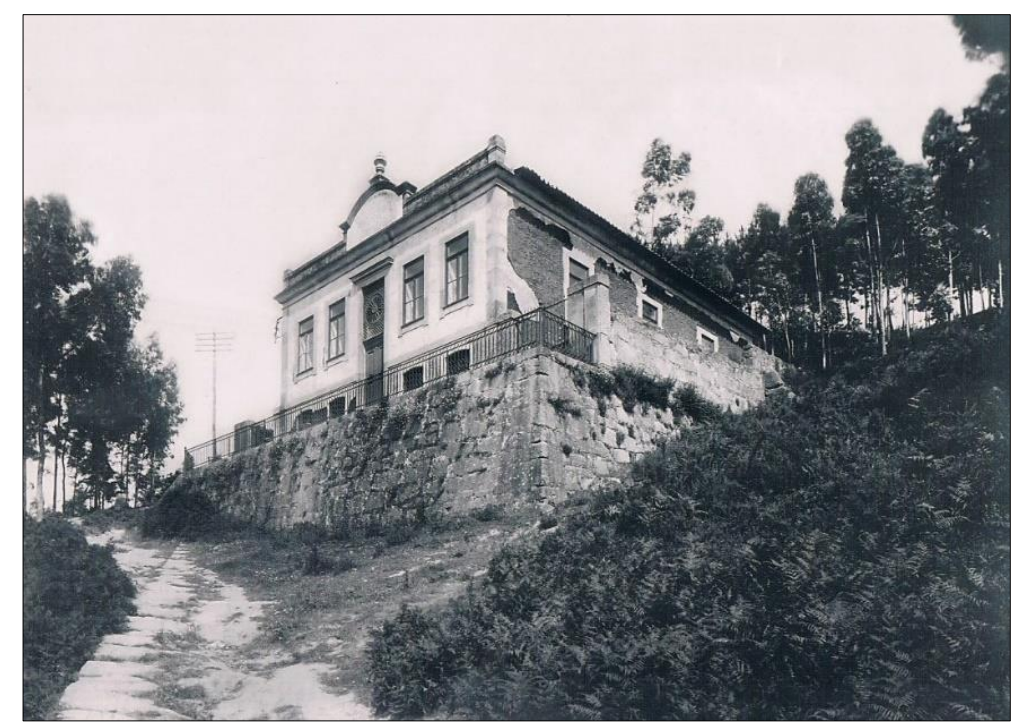

Fonte: Arquivo Documental da Associação das Creches de Santa Marinha. 
Fig. 4 - Edifício da primeira creche do casal Emília e António Costa.

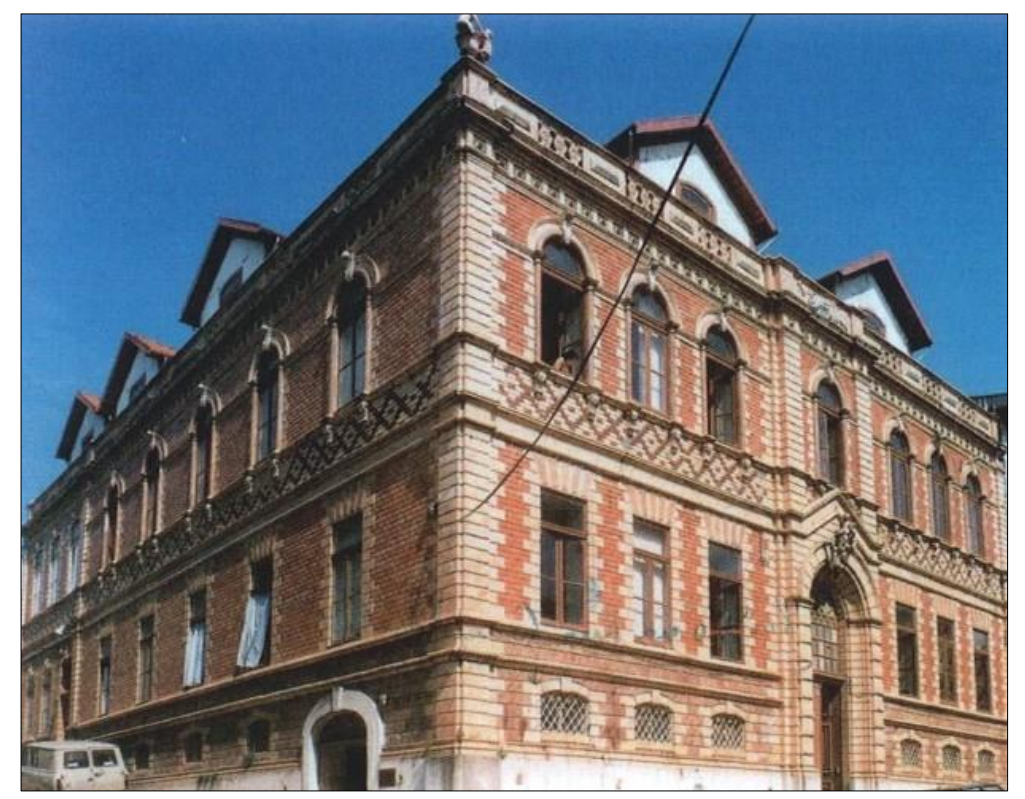

Fonte: Correia, 2014, p.184.

Pelo ano de 1894, funcionava num prédio que integrava o complexo Social da Fábrica de Cerâmica das Devesas ${ }^{28}$ um designado "Jardim Infantil" a expensas do casal proprietário. Este seria o embrião da Creche "D. Emília de Jesus", que veio a ser contruída e inaugurada em 1915 num edifício que, também, incluía instalações para asilo de velhos pelo que a instituição veio a designar-se "Asilo Creche e Hospital Emília de Jesus Costa e António Almeida Costa" 29 em memória dos seus fundadores. Em 2001 a creche é transferida para novas instalações.

Fig. 5 - Aspeto da fachada da "Creche Emília Jesus Costa e Asilo António Almeida da Costa".

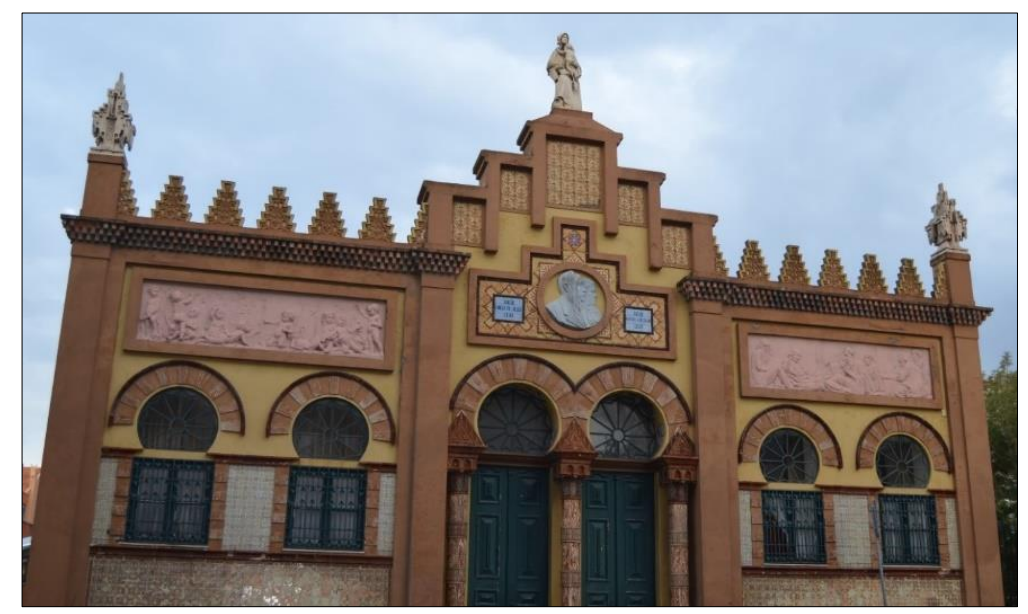

Fonte: Foto graciosamente cedida por Abel Barros.

\footnotetext{
${ }^{28}$ Situado na rua das Devesas, n. ${ }^{\circ} 189$.

29 Tinham preferência na admissão no Asilo os funcionários ou ex-funcionários da fábrica de Fundição e Cerâmica, e os filhos dos operários nas mesmas condições ou ainda de indivíduos que residissem há mais de dois anos no lugar das Devesas.
} 
Depois deste surto auspicioso, só volta a haver notícia da intenção de criar uma creche fabril em 1940, protagonizada pela Companhia de Fiação de Crestuma. Com efeito, a empresa obteve autorização para a construção de um edifício destinado a refeitório, balneário, salão de reuniões e uma creche projetada para o $1 .^{\circ}$ andar, sobre um compartimento destinado a armazenagem e venda de frutas. $\mathrm{O}$ espaço destinado à creche aceder-se-ia por uma escadaria em dois lanços e com dois ramos e estava dividido por um corredor de 4 metros de largura de acesso ao salão de reuniões. Dispunha de uma «pequena cozinha, uma sala de jantar para as crianças, um quarto para a empregada, um quarto com lavatórios para as crianças, um dormitório com 18 pequenas camas, um compartimento para rouparia e uma W.C.», sendo a iluminação feita por 6 amplas janelas. Todavia, um aditamento ao projeto datado de 1942, vem provar que apenas vieram a ser construídos o refeitório e os balneários (AMSMB/CMVNG Processo de Obras particulares em nome da Companhia de Fiação de Crestuma, 1940). A raridade e carestia dos materiais necessários, como consequência da instabilidade provocada pelo conflito mundial, adiaram estas obras ad perpetuam (TEIXEIRA, 2017: 172).

Fig. 6a - Aspeto da fachada do edifício em que incluíam espaços para creche da Companhia de Fiação de Crestuma (Pormenor).

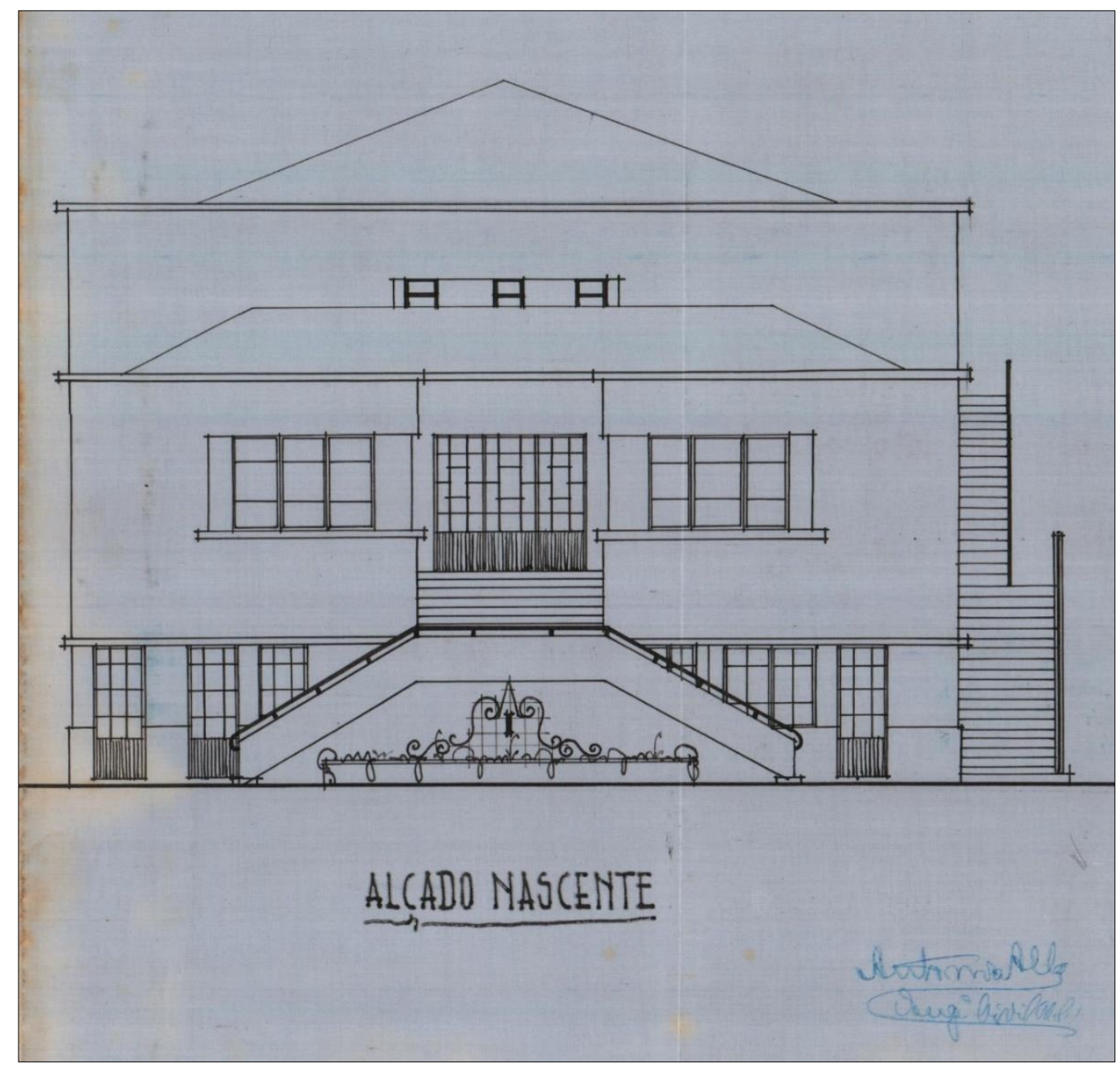

Fonte: AMSMB/CMVNG. Processo de Obras particulares em nome da Companhia de Fiação de Crestuma, 1940. 
Fig. 6b - Pormenor da planta relativa ao $1 .^{\circ}$ andar (sala de reuniões e creche).

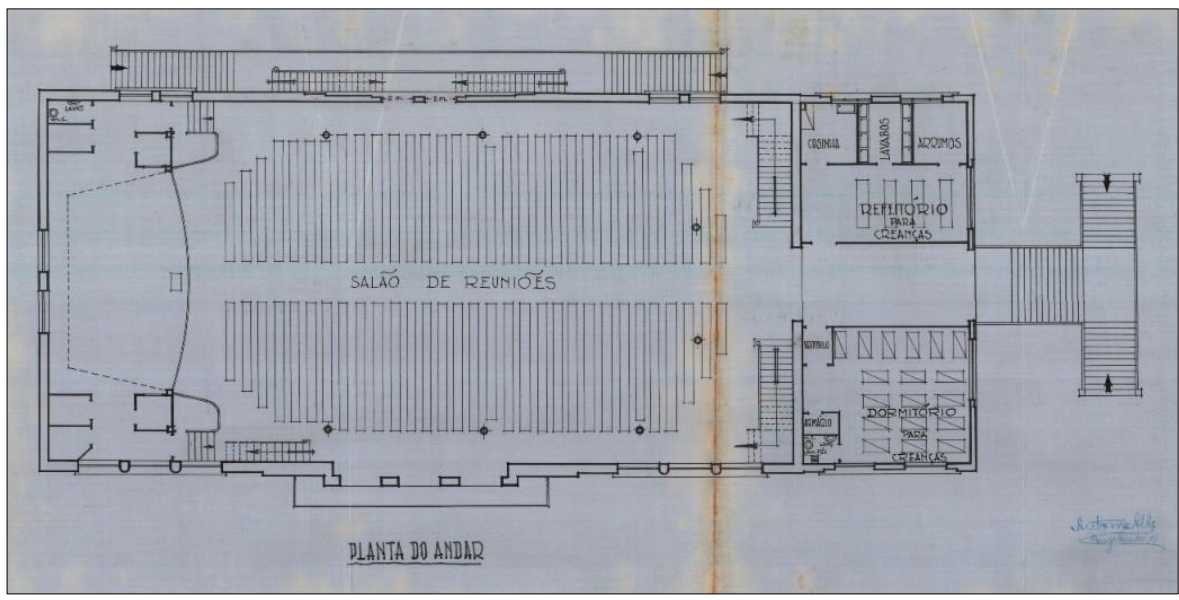

Fonte: AMSMB/CMVNG. Processo de Obras particulares em nome da Companhia de Fiação de Crestuma, 1940.

Também a creche dos Pobres de Valadares solicitada pela Assistência aos Pobres da mesma freguesia não chegou a ser concretizada. Esta agremiação sustentava a ideia da construção de um «abrigo-creche» para os filhos dos trabalhadores que se ocupam nos trabalhos fabris e na lavoura fossem «tratados convenientemente pelas senhoras da Congregação S. Vicente de Paulo». Os motivos apontados sugerem a preocupação pela dignidade e pelas condições de miséria da prole infantil da localidade: «[...] vendo-se por vezes crianças nas ruas umas completamente nuas outras com poucos farrapos sobre o corpo representando um perigo e um triste espetáculo para a sociedade» (AMSMB/CMVNG Processo de Obras particulares em nome da Assistência de Valadares, 1948).

Fig. 7 - Pormenor da fachada do projeto para a "Creche dos Pobres da Assistência de Valadares".

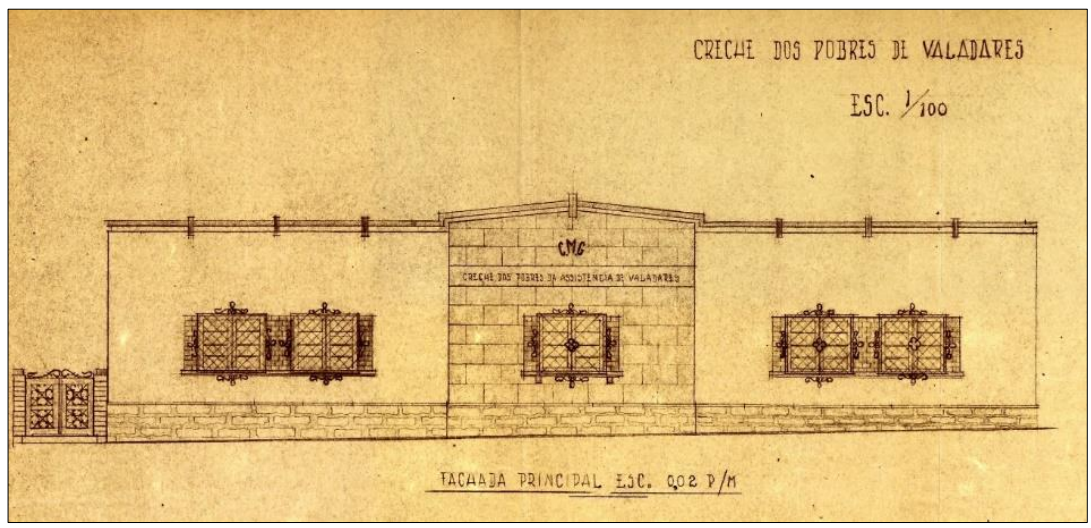

Fonte: AMSMB/CMVNG. Processo de Obras particulares em nome da Assistência de Valadares, 1948.

Com mais êxito, na freguesia de Mafamude, em 1942, a Companhia de Linhas Coats \& Clark abriu uma creche com assistência médica para os filhos menores dos funcionários. A obra, sob a direção de Agostinho Lopes Tavares, mestre-de-obras diplomado pela Escola Industrial Passos Manuel, empregou no edifício os melhores materiais, utilizando-se mosaico e azulejo no chão e paredes da cozinha, prevendo quarto de banho e retrete com sifão e a ligação de todos os esgotos ao saneamento geral existente na fábrica (AMSMB/CMVNG - Processo de Obras particulares em nome da Companhia de Linhas Coats \& Clark, 1942-3). A fábrica encerrou em finais do século XX, vindo a creche a ser adquirida pela Câmara Municipal. 
Fig. 8 - Pormenor da fachada da Creche Coats \& Clark.

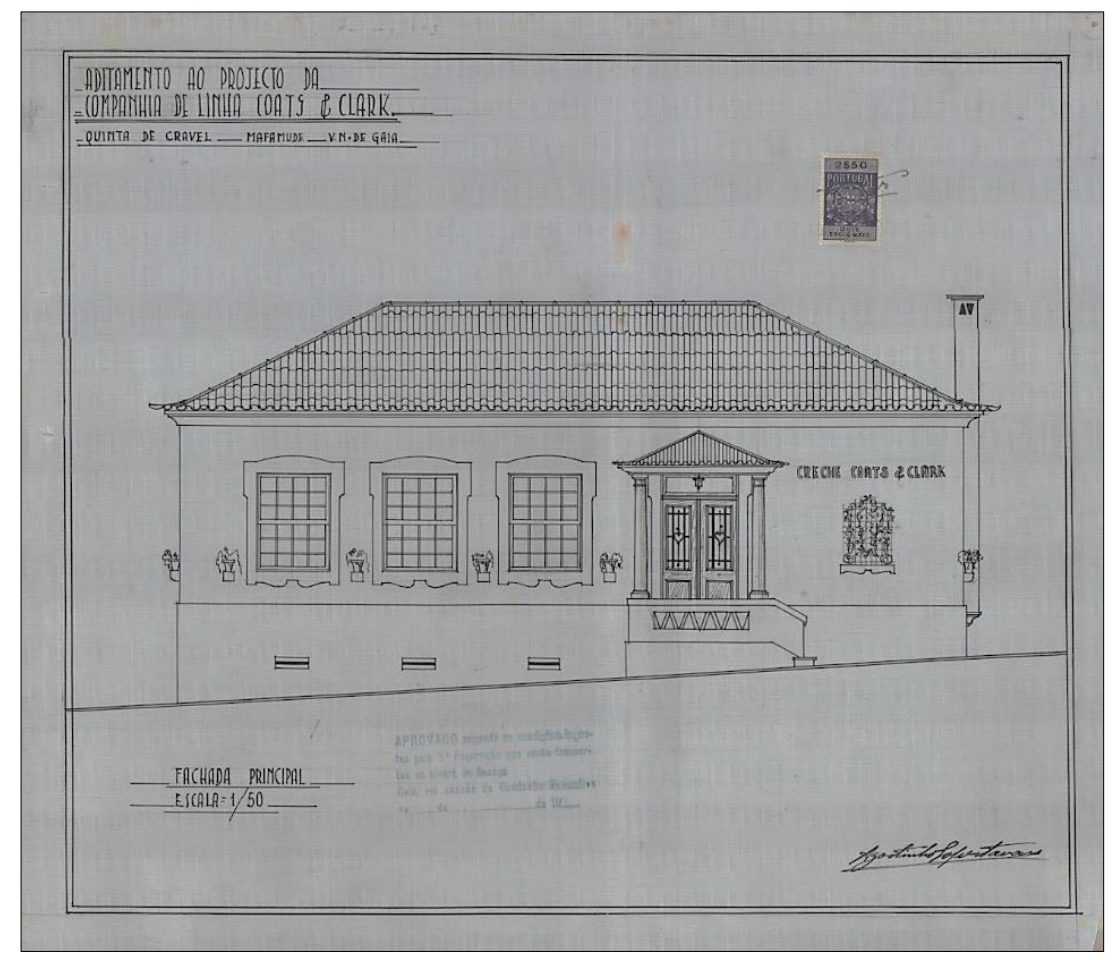

Fonte: AMSMB/CMVNG: Processo de Obras particulares em nome da Companhia de Linhas Coats \& Clark, 1942-3.

Em Arcozelo, a fábrica algodoeira D. Ferreira, Ld. a , criou um Lactário-creche modelar para filhos dos seus operários conforme se descreveu em respetiva "Memória descritiva". $\mathrm{O}$ complexo industrial é hoje um polo comercial, estando a creche desativada.

O edifício irá assentar um terreno salubre, será composto pelos aposentos indispensáveis e deverá alojar cinquenta crianças.

Os materiais a empregar, serão escolhidos, de forma a garantirem boas condições de higiene.

As fundações irão à profundidade necessária e ficarão com base suficiente para resistirem às cargas e que estão sujeitas. As paredes de elevação que serão parte em juntouros de 0,50 e parte em perpianho de 0,28 (como se verifica pelo projeto), crescerão desde a segunda sapata. Na altura conveniente serão asfaltadas para isolamento da unidade. A faixa será em cantaria rústica, assim como colunas, chapim, degraus e o portal da entrada principal. Todo o pavimento levará beton, que depois de bem isolado será colocado o mosaico ou cortiça. A armação levará as asnas necessárias, tendo vigamentos $0,23 \times 0,09$, barrotes $0,07 \times 0,06$ e ripa $0,04 \times 0,022$. Os tetos serão compostos por linhotes chaços e fasquio. As portas e caixilhos exteriores serão em madeira de castanho e as interiores em pinho. Todas as bandeiras de portas e caixilhos serão móveis.

A cobertura será em telha tipo "Mourisca" e os canos serão feitos com chapa zincada. As paredes exteriores serão ceresitadas e sobre o ceresit, rebocadas e estucadas, ficando cor-de-rosa, interiormente serão rebocadas e estucadas a branco. No pavimento do hall, cozinha, salas de preparação de leite e lavar, rouparia, lavabo, W.C., banho e farmácia, levarão mosaico e azulejo nas paredes na altura de 1,50, os 
restantes pavimentos levarão cortiça. A pintura em madeiras será feita a "Esmalte", ficando exterior castanho e interior branco. O vidro será vidraça Nacional. O abastecimento de água será feito dos poços existentes na propriedade. Nos trabalhos de sanidade, observa-se o disposto no Regulamento das Edificações Urbanas, aprovado por decreto de 14 de fevereiro de 1903 (AMSMB/CMVNG: Processo de Obras particulares em nome de D. Ferreira Ld. $\left.{ }^{a}, 1944-1951\right)$.

Fig. 9 - Pormenor da fachada da creche de Arcozelo.

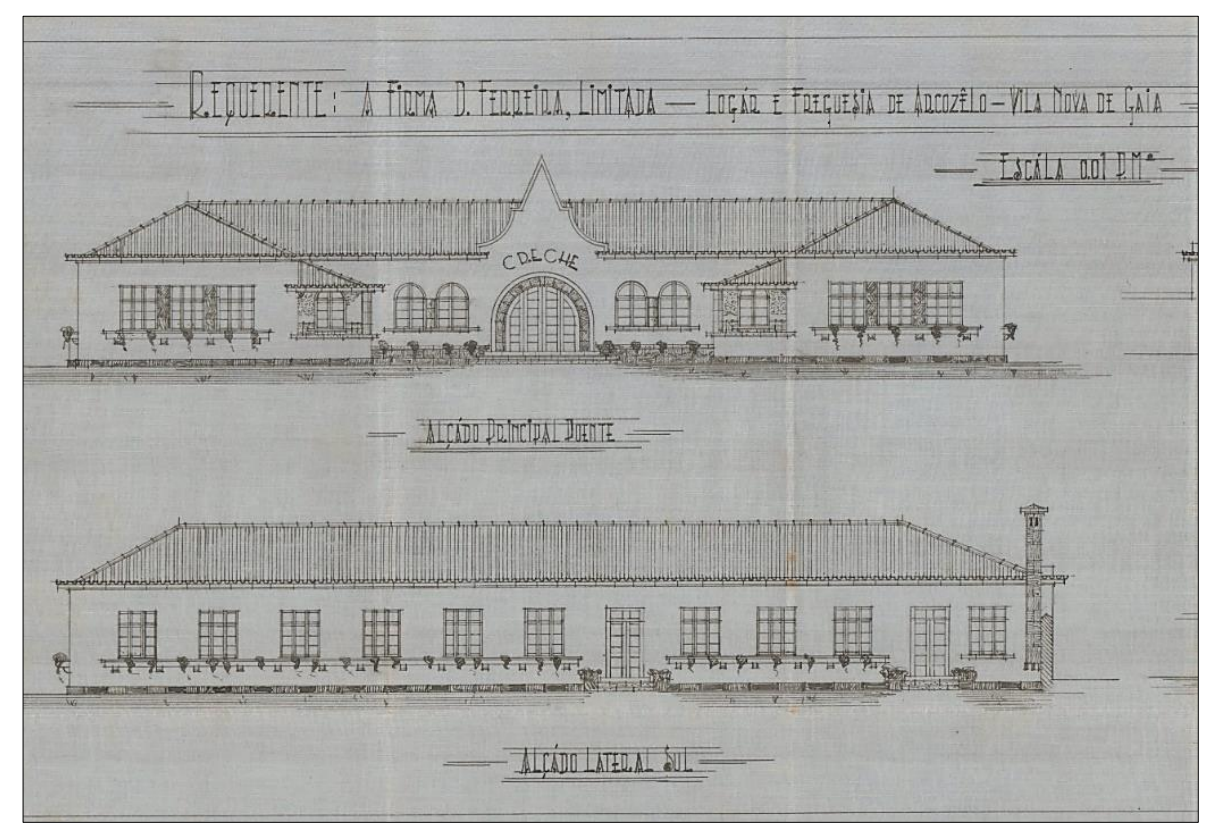

Fonte: AMSMB/CMVNG: Processo de Obras particulares em nome de D. Ferreira Ld. ${ }^{\text {a }, ~ 1944-1951 . ~}$

Relativamente às empresas de Vinho do Porto, sabemos que a Real Vinícola abriu uma creche em finais da década de 40 (AR-DP - Diário [...], n. ${ }^{\circ}$ 120, 1914: 30) e a Sociedade dos Vinhos do Porto Constantino, Lda. com vista à melhoria das instalações, apresenta, em 1956, um projeto para construção de um pavilhão para refeitório e cozinha, fazendo parte de um conjunto «uma pequena creche (dormitório, refeitório e sanitários) para crianças de idade inferior a 6 anos, filhas de operárias ao serviço» (AMSMB/CMVNG - Processo de Obras particulares em nome da Sociedade dos Vinhos do Porto Lda., 1956).

Já no princípio da década de setenta, na freguesia de Grijó, a Cotesi - Companhia de Têxteis Sintéticos, S.A.R.L., fundou uma creche para os filhos do pessoal, prevista para 100 crianças, 30 de peito e 70 entre os 1 e os 3 anos e meio. Este edifício, instalado junto ao bloco social das instalações fabris para fácil acesso das funcionárias antes das horas de trabalho, foi projetado para ser circundado por rede e sebe vegetal, amplos espaços destinados a jardim e arrelvamentos, sendo na parte poente localizado um parque infantil e de diversão, com balancés e outros brinquedos, incluindo vasta arborização. As instalações, que além de lactário, berçário, «sala das crianças mais crescidas», refeitório, copa, cozinha, despensa, lavandaria, sanitários e gabinetes, incluíam também oficina, gabinete médico, espaço de isolamento de crianças doentes, entre outros. Para as cozinhas, sanitários e lavandaria destinaram-se pavimentos em mosaico de marmorite, lambrins de azulejo branco e as paredes de todas as dependências tratadas com tinta vitrificante lavável até à altura das portas. Em relação ao interior, destinou-se a aquisição de mobiliário simples e funcional, sendo empregues materiais antitóxicos e de fácil lavagem nas zonas de serviço (tampos e balcões da copa e cozinha), «por forma a que sejam 
manipuladas todas as refeições com a maior higiene e asseio possíveis». Além das preocupações higienistas e de segurança, este projeto de Jerónimo Ferreira Reis, demonstrava ainda sensibilidades estéticas patentes, por exemplo, na idealização da fachada, sendo as superfícies principais revestidas a tijoleira cerâmica vidrada e os restantes elementos da argamassa pintados em tinta plástica com os tons do local (AMSMB/CMVNG - Processo de Obras particulares em nome de D. Ferreira Ld. ${ }^{\text {a }}$, 1944-1951).

Fig. 10 - Pormenor da fachada da Creche da Cotesi - Companhia de Têxteis Sintéticos, S.A.R.L.

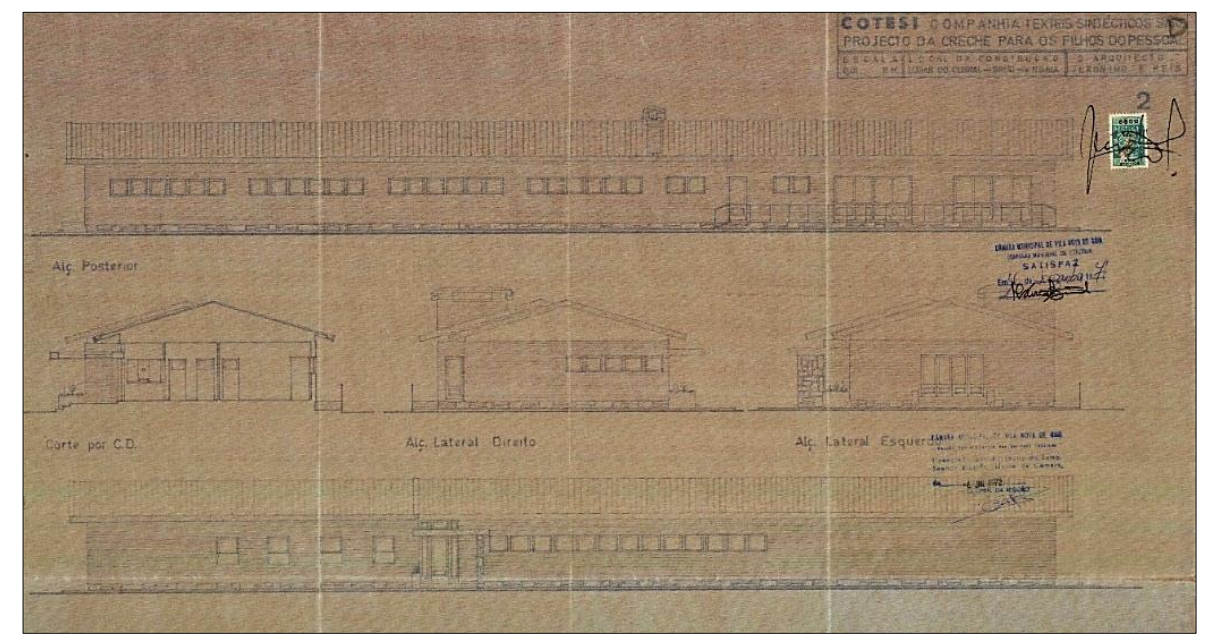

Fonte: Fonte: AMSMB/CMVNG: Processo de Obras particulares em nome de COTESI - Companhia de Têxteis Sintéticos S.A.R.L., 1971.

\section{Considerações finais}

A instituição creche insere-se no grupo de instituições que cuidavam de crianças em idade pré-escolar, mas nem sempre são claros os limites etários permitidos e muito menos as filosofias educativas orientadoras. $\mathrm{O}$ facto de acolherem crianças muito pequenas inscreveu-as num nicho assistencioeducativo, onde as novas pedagogias foram penetrando com pouco rumor, alicerçadas, sobretudo, na educação veiculada pelo exemplo materno e práticas educativas das regentes e na filantropia socialmente proeminente e reguladora. Tuteladas por agremiações, a documentação é praticamente inexistente no que concerne às questões de quotidiano das crianças, além da alimentação, da higiene e dos óbolos oferecidos.

Criadas no século XIX para dar resposta a necessidades sociais que foram crescendo com a progressiva entrada da mulher no mundo do trabalho, as creches estiveram sempre em grande desequilíbrio em relação às reais necessidades, sendo disso flagrante exemplo o território em estudo. Na ausência de um Estado Providência, a filantropia burguesa e aristocrata, a maçonaria e a assistência religiosa, sustentaram as creches até ao Estado Novo, que tolerou a sua existência como um mal menor no contexto urbano.

Se até à República as creches se inscreviam no processo a que chamaram "aurora" da educação, durante a ditadura as creches esconderam miseráveis, evitando os tais «tristes espetáculos para a sociedade». O cariz eminentemente assistencialista da educação em creche acentuou-se durante o Estado Novo, quando as escassas instituições em funcionamento assentaram, sobretudo, numa perspetiva caritativa, sendo-se pouco exigente, não só na especialização do pessoal, como na própria arquitetura da maioria dos espaços.

A relação do eugenismo com a emergência das creches esteve latente até meados do século XX, altura em que a Infância é "legislada" através da "Declaração dos Direitos da Criança" e os discursos políticos, alicerçados nas ciências sociais, enveredaram pela des/igualdade das crianças à entrada da escolaridade. 
O estudo reflete a generalidade da realidade urbana portuguesa. Antes de mais, a creche, em Vila Nova de Gaia, encarada pela maior parte dos protagonistas, sobretudo, como instituição de caridade, assistencial, imbuiu-se de uma certa invisibilidade no seu esforço difusor da especificidade inerente à primeira infância. Por outro lado, não obstante o arranque promissor de finais do século XIX, a expansão da rede de creches retraiu-se, ao longo do século XX, sendo a sua criação resultante, sobretudo, da iniciativa fabril e empresarial e já não filantrópica como na sua génese, concentrada sempre nas freguesias de Santa Marinha e Mafamude. Das freguesias rurais, que constituem a maior parte do território, não há notícia de "criadeiras" ou creches, sendo que na maioria dos casos, as crianças acompanhavam os pais no trabalho.

\section{Fontes Impressas}

A Defesa. n. ${ }^{\circ}$ 51, 1906.

A Mocidade. n. ${ }^{\circ}$ 9, 1897.

A Mocidade. n. ${ }^{\circ}$ 11, 1898.

Assembleia da República-Debates Parlamentares. Diário da Câmara dos Deputados. n. ${ }^{\circ}$ 120, 1914.

Assembleia da República-Debates Parlamentares. Diário das Sessões Assembleia Nacional. n. $^{\circ} 181,1938 ;$ n. $^{\circ} 63,1944 ;$ n. $^{\circ} 181,1938 ;$ n. $^{\circ} 81,1969 ;$ n. $^{\circ} 98,1971 ;$ n. $^{\circ} 34,1974$.

COSTA, António. Auroras da instrução pela iniciativa particular. Lisboa: Imprensa Nacional, 1884.

O Portucalense. n. ${ }^{\circ}$ 33, 1906.

PORTUGAL. Decreto de 22 de dezembro de 1894, aprovado em 18 de junho de 1896.

PORTUGAL. Decreto de 23 de agosto de 1911.

PORTUGAL. Decreto do Ministério do Interior de 29 de março de 1911.

PORTUGAL. Decreto n. ${ }^{\circ} 14498$ de 29 de outubro de 1927.

PORTUGAL. Decreto n. ${ }^{\circ} 14535$ de 31 de outubro de 1927.

PORTUGAL. Decreto Regulamentar n. ${ }^{\circ}$ 69/83 de 16 de junho.

PORTUGAL. Decreto-Lei n. ${ }^{\circ} 30 / 89$ de 24 de janeiro.

PORTUGAL. Decreto-Lei n. ${ }^{\circ}$ 5787-A de 10 de maio de 1919.

PORTUGAL. Despacho n. ${ }^{\circ}$ 9180/2016, de 19 de julho.

PORTUGAL. Diário da República n. ${ }^{\circ}$ 162/1983, Série I de 1983-07-16, Decreto PORTUGAL. Regulamentar 69/83, de 16 de junho.

PORTUGAL. Diário da República n. ${ }^{\circ}$ 294/1981, Série I de 1981-12-23, Decreto-Lei n. ${ }^{\circ}$ 350/81, de 23 de dezembro.

PORTUGAL. Diário do Governo n. ${ }^{\circ}$ 141, de 27 de junho de 1896.

PORTUGAL. Diário do Governo n. ${ }^{\circ}$ 240/1927, Série I de 1927-10-29, Decreto 14498, de 29 de outubro.

PORTUGAL. Diário do Governo n. ${ }^{\circ}$ 240/1927, Série I de 1927-10-29.

PORTUGAL. Diário do Governo, n. ${ }^{\circ} 141$ de 27 de junho de 1896.

PORTUGAL. Lei de Bases do Sistema Educativo, Lei n. ${ }^{\circ}$ 46/86 de 14 de outubro.

PORTUGAL. Lei n. ${ }^{\circ}$ 5/77.

PORTUGAL. Lei n. ${ }^{\circ}$ 5/97 de 10 de fevereiro (Lei - Quadro da Educação Pré-Escolar).

PORTUGAL. Portaria n. ${ }^{\circ}$ 262/2011 de 31 de agosto. 
PORTUGAL. Projeto de lei n. ${ }^{\circ}$ 66/XXXII/1. ${ }^{\mathrm{a}}, 1897$.

PORTUGAL. Proposta de Lei 22 de julho de 1923.

\section{Fontes Manuscritas}

ADP - Arquivo Distrital do Porto

Estatutos de A Infantil. Associação de Socorros Mútuos, 1909.

ADCSM - Acervo Documental Creches de Santa Marinha

Livro de Actas [1929-1936]: 70v.

AMSMB/CMVNG - Arquivo Municipal Sophia de Mello Breyner/Câmara Municipal de Vila Nova de Gaia

Processo de Obras particulares em nome da Companhia de Fiação de Crestuma, 1940.

Projeto de uma Creche na freguesia de Valadares, 1948.

Processo de Obras particulares em nome da Companhia de Linhas Coats \& Clark, 1942-3.

Processo de Obras particulares em nome de D. Ferreira Ld. ${ }^{a}, 1944-1951$.

\section{REFERÊNCIAS}

ABREU, Carlos. Vaz, Ângelo Alves de Sousa. In: NÓVOA, António. Dicionário de Educadores Portugueses. Porto: ASA, 2003, p. 1418-9.

ALMEIDA, Paulo. A Maçonaria no Porto durante a 1. ${ }^{\text {a }}$ República. Lisboa: Chiado Editora, 2015.

BAIRRÃO, Joaquim e VASCONCELOS, Teresa. A educação pré-escolar em Portugal: contributos para uma perspetiva histórica. Inovação, n. ${ }^{\circ}$ 10, p. 7-19, 1997.

BANDEIRA, Filomena. Assistir e educar a infância na modernidade: espaços de acolhimento, lugares de memórias. Lisboa: Santa Casa Misericórdia, 2010, p. 76-103.

BAPTISTA, Eva. Associação das Creches de Santa Marinha. Espaço de Modernidade Educativa. Vila Nova de Gaia: Associação das Creches de Santa Marinha/CITCEM, 2018.

CARDONA, Maria João. Para a história da educação da infância em Portugal: o discurso oficial (1834-1990). Porto: Porto Editora, 1997.

CARVALHO, Mônica. A invisibilidade social da creche como espaço educativo. Porto: Faculdade de Psicologia e de Ciências da Educação da Universidade do Porto. Dissertação de Mestrado, 2014. https://doi.org/10.21011/apn.2017.1207

CASTANHEIRA, Manuel Luís Pinto. Para a História da Educação de Infância em Portugal: o caso de Bragança (1934-1986). Universidade de Lisboa: Tese de Doutoramento, 2013. https://doi.org/10.17013/risti.27.109-125

CORREIA, Fernando António da Silva. A Misericórdia: a Santa Casa de Vila Nova de Gaia. Vila Nova de Gaia: Santa Casa da Misericórdia de Vila Nova de Gaia, 2012. https://doi.org/10.32932/pjnh.2019.03.001 
CORREIA, Fernando António da Silva. António Almeida da Costa. Vila Nova de Gaia: Santa Casa da Misericórdia, 2014.

COSTA, Virgília Braga da. As condições higiénico-sanitárias e as doenças infeciosas em Vila Nova de Gaia na 2. ${ }^{a}$ metade do século XIX e nos primeiros anos do século XX. Boletim da Associação Cultural Amigos de Gaia, vol. 10, n. ${ }^{\circ}$ 60. Vila Nova de Gaia: ACAG, p. 45-48, 2005. https://doi.org/10.17925/enr.2015.10.02.157

DIAS, Regina Celia, CORREIA, José Alberto e PEREIRA, Maria de Fátima. A creche e a construção da cidadania de mulheres e crianças em Portugal. Revista Educação Pública. vol. 22, n. ${ }^{\circ}$ 50. Cuiabá (Brasil), p. 665-685, 2017.

FELGUEIRAS, Margarida Louro. A educação e a escolarização da infância em Portugal (1910-1974). Linguagens, Educação e Sociedade: revista do Programa de PósGraduação em Educação da UF, ano 17, n. ${ }^{\circ}$ 26. Teresina (Brasil): Universidade Federal do Piauí, p. 17-42, 2012. https://doi.org/10.29280/rappge.v2i2.4342

FERREIRA, António Gomes; MOTA, Luís; VILHENA, Carla Cardoso. Discursos sobre a emergência da educação da infância formal em Portugal (1880-1950). Revista História da Educação (online). v.23: e.85647, 2019. https://doi.org/10.1590/2236-3459/85647

GOMES, Joaquim Ferreira. A educação Infantil em Portugal. Coimbra: Livraria Almedina, 1977.

GOMES, Joaquim Ferreira. Estudos para a História da Educação no século XIX. Coimbra: Livraria Almedina, 1980.

GUIMARÃES, Hercília; FERRAZ, Amélia Ricon. Sobre a mortalidade infantil (até aos 5 anos) na cidade do Porto e os meios de a evitar. Porto: Faculdade de Medicina, 2008. Facsimile de GARRETT, António de Almeida. Porto: Typ. A Vapor da Empresa Guedes, 1908. https://doi.org/10.23911/comentario_faculdade_de_medicinado_porto

LEANDRO, Maria Elisa. Lisboa, Irene do Céu Vieira. In: NÓVOA, António, dir. Dicionário de Educadores Portugueses. Porto: Edições ASA, 2003, 773-784.

MAGALHÃES, Justino Pereira de. Para uma história da educação da infância em Portugal. Saber (e) Educar. n. ${ }^{\circ}$ 2. Porto: ESE Paula Frassineti, p. 21-26, 1997.

MARQUES, A. H. Oliveira. Dicionário de Maçonaria Portuguesa. vol. 1. Lisboa: Delta, 1986.

MARTINS, Ernesto Candeias Martins. O discurso oficial da educação de infância: um antes e um depois. Revista Intersaberes. vol. 1, n. ${ }^{\circ}$ 1, p. 101-136, 2006.

MARTINS, Ernesto Candeias. O discurso oficial da educação de infância: um antes e um depois. Revista Intersaberes. vol. 1, n. ${ }^{\circ}$ 1, p. 101-136, 2006.

MIRANDA, Sacuntala. A base demográfica. In: MARQUES, A. H. de Oliveira (coordenador) Nova história de Portugal: Portugal da Monarquia para a República. vol. 11. Lisboa: Editorial Presença, p. 13-36, 1991. 
PESSOA, Ana Maria Pires. A educação das mães e das crianças no Estado Novo: a proposta de Maria Lúcia Vassalo Namorado. Lisboa: Universidade de Lisboa/ Faculdade de Psicologia e Ciências da Educação. Tese de doutoramento, 2005. https://doi.org/10.32932/rpia.2019.03.002

PIMENTEL, Irene Flunser. A assistência social e familiar do Estado Novo nos anos 30 e 40. Análise Social. vol. 34 (151-152), p. 447-508, 1999.

PINTO, Jorge. A creche em Portugal: entre uma perspetiva assistencialista e educacional. Mediações: revista OnLine da Escola Superior de Educação do Instituto Politécnico de Setúbal. vol. 3, n. ${ }^{\circ}$ 2, 2015. https://doi.org/10.22355/exaequo.2017.36.05

REMA, Henrique Pinto (organização). Crónica do Centenário da Congregação das Irmãs Franciscanas Hospitaleiras da Imaculada Conceição: 1871-1976. [S.1.: s.n.]. Braga: Tip. Editorial Franciscana, 2008.

SANTOS, Licínio. Cultura e Lazer Operários em Gaia, entre o final da Monarquia e o início da República (1893-1914). Vila Nova de Gaia: Amigos do Solar Condes de ResendeConfraria Queirosiana/ Edições $\quad$ Afrontamento, 2017. https://doi.org/10.21747/9789898351708/hist2017

SILVA, António. Torne: Um lugar na História 1868-2018. Vila Nova de Gaia: Igreja Lusitana Católica, Apostólica, Evangélica, 2018.

SILVA, Isabel Lopes da, (coordenação). Orientações curriculares para a educação PréEscolar. Lisboa: Ministério da Educação/ Direção-Geral da Educação (DGE), 2016. https://doi.org/10.19091/reced.v0i0.108

SOUSA, Fernando. A Maçonaria do Porto e a Revolta Republicana de 1861. Porto: Livros Horizonte, 1991, p. 391-409.

TADEU, Bárbara. A legislação portuguesa para a pequena infância: uma visão sociológica sobre a infância. Interacções, n. ${ }^{\circ}$ 30, p. 159-175, 2014.

TEIXEIRA, Maria de Fátima. Companhia de Fiação de Crestuma: do fio ao pavio. Dissertação de Mestrado, Universidade do Porto, 2017.

TOMÉ, Maria Rosa. A cidadania infantil na Primeira República e a tutoria de infância. A criação da tutoria de Coimbra e do Refúgio anexo. Revista de História da Sociedade e da cultura. t. 2. Coimbra: Centro de História da Sociedade e da Cultura/ Universidade de Coimbra, p. 481-500, 2010. https://doi.org/10.14195/1645-2259_10-2_6

VENTURA, António. Os Constituintes de 1911 e a Maçonaria. Círculo de Leitores e Temas e Debates, 2012, p. 95-96. 